\title{
Ecological Planning and Ecotourism Development in Kimbi Game Reserve, Cameroon
}

\author{
Ndenecho Emmanuel Neba \\ Geography Department, University of Yaounde I, ENS Annex Bambili, P.O. Box Bamenda \\ North West Province, Cameroon \\ E-mail: ndenechon@yahoo.com
}

KEYWORDS Ecotourism. Reserve. Sustainability. Livelihoods. Ecological Planning. Integration

\begin{abstract}
Game reserves and other protected areas are potential areas for the development of ecotourism because of their biodiversity, landscapes and cultural heritage of local or indigenous people. This study investigates the environmental sustainability of game reserves using a sample of the Kimbi Game Reserve. It assesses the potentials of the reserve for the development of ecotourism by employing a combination of field observation, examination, data collection and evaluation, using a SWOT analysis. The SWOT analysis determines opportunities and threats, and strategic suggestions for ecological planning. The study determines usage potential and the types of ecotourism feasible for development, and appraises the current management strategies. It concludes that ill-adapted strategies are bound to fail in promoting ecotourism, attaining sustainable landscapes and livelihoods. The Kimbi Game Reserve has economic potential for ecotourism which can be realized by integrating the cultural values, livelihoods and environmental awareness of local people in tourism development. Finally, the paper recommends that in this process, government organizations, universities and research institutions must interact sufficiently in order to develop the potential of interest to ecotourism, ecocultural tourism and scientific tourism. It suggests ways to ensure that tourism is ecologically and socially beneficial.
\end{abstract}

\section{INTRODUCTION}

The main focus of most interpretations of sustainable development is the reorientation of understanding society in relation to nature (Redclift 2000). Even though this focus does not necessarily imply such an outcome, most implementation of sustainability has been satisfied with the integration of environmentally sound practices and policies into development programmes and projects (Chifos 2006; Lele 1991). Building on the foundation of increasing environmental awareness, interpretation of economic development as integral to environmental and social systems has gained momentum and has been expressed in a variety of ways, such as redesign of economic processes to work with nature instead of against it (McDonought and Braungart 2002) or rethinking the linkages among livelihood strategies, poverty alleviation and environment (Neefjes 2000; Chambers 1992). Thus, the physical and biological, environmental and economic components of the world system are firmly ingrained in the interpretation and operationalisation of sustainable development.

Protected areas in several countries have been damaged when important ecological aspects of such areas have not been considered. In these areas, plans based on ecological data are needed for land use planning, improvement and development (Jurgen 1993). In most developing countries the purpose of protected areas is to conserve biodiversity and so have failed to recognize the realities of their local socio-cultural and economic environments (Ndenecho 2007). According to Ndenecho (2005) they must protect the cultural, natural and traditional activities of people against the consequences of rapid progress. Effective plans need to conduct all relevant biological, social, physical and economic factors and focus on important resources affecting the ecological integrity of the areas (Gengiz 2006; Sanderson et al. 2002).

Several studies conducted in protected areas have focused on ecotourism or nature tourism as a form of sustainable tourism (Poiani et al. 1998; Danial et al. 2005). Recently research has focused on how protection of local ethnicity can be achieved without impacting on the life of local people by linking social life and environmental protection (Gregory 2005; Barkin 1996). Ecotourism has been suggested as a key to sustainable development of protected areas (Barkin 1996). It provides investment for tourism and enhances the living standards of local people by providing opportunities for employment. Cultural investments, such as historic preservation or dissemination of traditional skills, can also work to 
provide economic benefits while preserving connectivity with the past (Chifos 2006), that is, it is nurtured and disseminated as poverty is alleviated.

The general trend in ecotourism is to increase experiences by encouraging activities such as long-distance walking, camping, boating, hunting, sight-seeing, swimming, cultural activities, bicycling, observing wildlife and nature, skiing, visiting historical places, and horse riding among others. Generally, instructive activities, for example, wildlife observation, participation in festivals, cultural activities and nature landscapes, attract most attention (Gengiz 2007). In this study, the potential for the sustainable development of ecotourism is assessed in a sample of the Kimbi Game Reserve and the adjacent rural communities. The study was designed to determine the potential use of the area and to suggest ecotourism types likely to be beneficial for local people. It stresses the need for ecological planning and the linking of livelihoods with environmental protection projects.

\section{THE STUDY AREA}

The grid reference of the study area is Latitudes $6^{\circ} 5^{\prime} \mathrm{N}$ and $6^{\circ} 40 \mathrm{~N}$, and longitudes $10^{\circ}$ $19^{\prime} \mathrm{E}$ and $10^{\circ} 24^{\prime} \mathrm{E}$. The total land surface area covered by the reserve is 6000 hectares (Fig. 1). There are 13 villages around the reserve. The altitudinal range is between 950 and $1500 \mathrm{~m}$ above sea level. Hawkins and Brunt (1995) have described the climate as a "sub-montane cool and misty climate" with an annual mean maximum temperature of $20^{\circ} \mathrm{C}$ to $22^{\circ} \mathrm{C}$ and mean minimum of $13^{\circ} \mathrm{C}$ to $14^{\circ} \mathrm{C}$. Annual rainfall varies between $1780 \mathrm{~mm}$ and $2290 \mathrm{~mm}$. Most of the rainfall occurs between July and September. A dry season occurs from mid - October to mid-March.

Geographically the area is part of the Cameroonian Highlands ecoregion which encompasses the mountains and highland areas of the border region between Nigeria and Cameroon (Stuart 1986). The area falls within the Afromontane archipelago-like regional centre of endemism that spans the entire African continent. The forests in the area are refugia in montane and sub-montane environments. Conservation efforts have tended to emphasize the protection of biodiversity and so have ignored local livelihoods.

The area is sparsely inhabited by small chiefdoms. In 2005 the population was 1,071 inhabitants with an annual growth rate of $0.85 \%$. By 2015 it is projected to be 1,165 inhabitants.

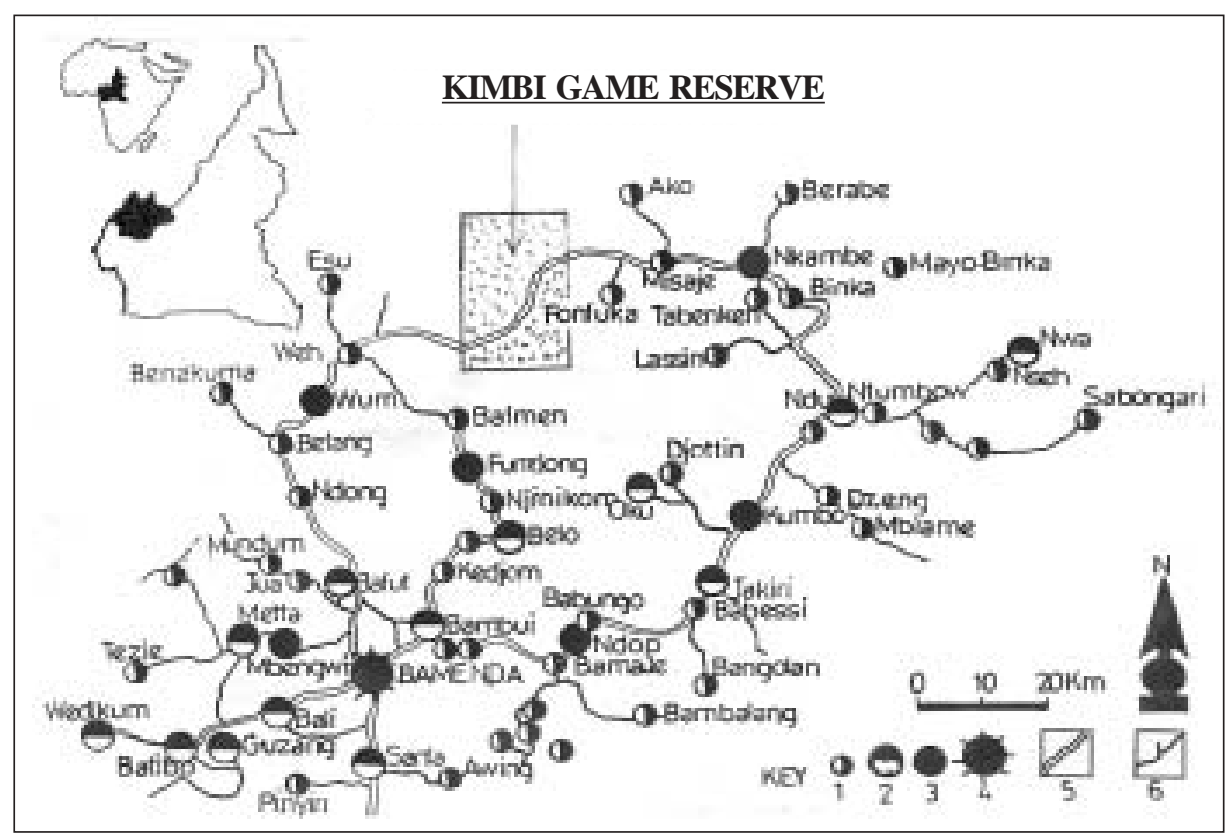

Fig. 1. Location of the study area with the rural market structure and urban centres: 1. Rural markets; 2. Regional markets; 3. Urban centres; 4. Regional capital; 5. Primary roads; 6. Secondary roads. 
These are subsistence farmers. Poverty is rife in the area as a result of an economy that thrives on subsistence agriculture that yields little income. Unfortunately, the political and economic system which fails to provide local people with land, jobs and food, obliges disenfranchised people to turn to legally protected lands, plants and animals for their needs. Under these circumstances, immediate human survival always takes precedence over long-term environmental goals. However, the government of Cameroon is beginning to realize that ecotourism can be more beneficial to local people in the region over the long-term than traditional extractive activities.

The montane forests are of great ecological significance. They contain several endangered species of plants and animals (Alpert 1993; Ngwabuh 2002). The area is spectacularly beautiful. Several volcanic episodes have created crater lakes, maars and strombolian cones. The reserve is in the Nyos volcanic District, with active gas eruptions and several thermo-mineral springs. The association of fissural and strombolian eruptions produced numerous spatter cones which give outstanding panoramas over the rift basins, forested valleys, and rugged grasslands. The magnificent views, unique wildlife and rich culture all have great tourist potential which could be realized with careful development. Tourists and scientists have shown interest in the wildlife and in the seismic processes of the area.

The game reserve was created in 1963 with the objective of promoting tourism and the improvement of the socio-economic development of the local communities. The reserve status has since remained on paper with little infrastructural investments and promotion of local livelihoods. In recent years it has come under serious threats from geological processes such as lake-basin gas eruptions and anthropic activities.

\section{METHODOLOGY}

The study focused on the Kimbi Game Reserve and the forest-adjacent villages. Study methods included field observations, data collection and evaluation, using a SWOT analysis. A data base of the reserve was used to derive data on wildlife resources. The Soft Systems Methodology (SSM) which includes Participatory Rural Appraisal (PRA) and Rapid Rural Appriasal (RRA) philosophy was employed to evaluate the current situation. Field observations, informal interviews and secondary data sources yielded data on ecotourism potentials. These were mapped from base maps and updated using field observations and a global positioning system. Base maps and aerial photographs were produced by the National Geographic Institute. The SWOT analysis focused on seven forest adjacent villages (Fig. 2). The advantages and disadvantages of the reserve were determined with regard to tourism. The analysis was done by determining opportunities and threats and strategic suggestions were presented for ecological planning. In this way a sound understanding of elements, process and practice of local institutions was gained in order to determine appropriate interventions.

\section{RESULTS AND DISCUSSIONS}

As the world shrinks, tourists look for new destinations and new experiences. The Highland ecoregion offers both, with fascinating flora and fauna and new climates and terrains. The destinations and experiences in the area include nature landscapes, fascinating wildlife and a rich cultural heritage.

\section{New Landscapes}

The area is broken into plateau, fault blocks and steep escarpments. Several recent volcanic episodes have created strombolian cones, crater lakes and maars. The characteristics of the lakes are presented in table 1 .

The slopes are littered with landslide scars and some thermo-mineral springs. The physical and chemical properties of these sources may be beneficial for medical purposes, but there are no commercial facilities for using their water. The lakes have not been developed for commercial purposes. This volcanic district which in 1986 was mapped out as a disaster zone and the villagers re-located lies to the south of the game reserve. Its fascinating landscapes and grass savannahs could be carefully developed as part of the reserve (Fig. 2).

\section{Wildlife Resources}

Wildlife is protected in the Kimbi Game Reserve. It has important potential in terms of flora which has attracted the interest of the 
Fig. 2. The Kimbi Game Reserve and Feasible zones for the development of ecotourism. LEGEND: 1: Kimbi Game Reserve, 2: Picturesque zone feasible for the extension of the reserve, 3: Picturesque toxic gas eruption-prone zone feasible for the extension of the reserve, 4: Office and residence of the conservator, 5: Villages, 6: Earth road, 7: Major footpaths, 8: Lakes, 9: Mountain divide, 10: Rivers

International Union for the Conservation of Nature and Natural Resources (ICUN), The World Wildlife Fund (WWF) and the International Council for Bird Preservation (ICBP). It has been identified as one of the most at risk terrestrial ecological regions (Macleod 1986; Stuart 1986; Alpert 1993). A total of 98 plants are recorded in the reserve (Table 2). These belong to 43 plant families (Kwanga 2006). The ecoregion as a whole has one of the highest levels of endemism in the whole of Africa, particularly among birds and vascular plants. For example, 20 bird species are found only in this ecoregion (Stuart 1986).

Table 3 presents the 21 mammals recorded in the reserve. The population drastically reduced since 1973. It was reported that the once abundant species are rarely sited. This is attributed to grazing and farming encroachment, poaching, fire encroachment and poor implementation and management of the reserve status despite the scientific importance of the flora and fauna. A total of 203 bird species are recorded in the reserve (Table 4). These include 45 of the 215 GuinoCongo forest biome bird species and 8 of the 45 bird species restricted to the Sudan-Guinea Savannah. Species of interest include the brownchested plover (Venellus supercilious). This is an uncommon and local intra-African migrant found to breed in Cameroon and Nigeria (Alpert 1993). Povel's illadopsis (Illadopsis puveli) is an uncommon resident in the northern part of the reserve and outlier in savannah flock of 6 birds mostly observed in gallery forests in the Jonja River Valley. The bird life is threatened with habitat loss and fragmentation.

The main attractions are the lakes, the dark

Table 1: Lakes South of the Kimbi game reserve in the nyos volcanic district.

\begin{tabular}{lllrrrr}
\hline S. No. & Lakes & Latitude & Longitude & Altitude $(m)$ & Area (hectares) & Depth $($ metres) \\
\hline 1. & Enepe & $6^{\circ} 18^{\prime} \mathrm{N}$ & $10^{\circ} 02^{\prime}, \mathrm{E}$ & 697 & 50 & 78 \\
2 & Wum & $6^{\circ} 24^{\prime} \mathrm{N}$ & $10^{\circ} 03^{\prime}, \mathrm{E}$ & 1177 & 45 & 124 \\
3 & Njupi & $6^{\circ} 25^{\prime} \mathrm{N}$ & $10^{\circ} 18^{\prime} \mathrm{E}$ & 1020 & 30 & $?$ \\
4 & Nyos & $6^{\circ} 26^{\prime} \mathrm{N}$ & $10^{\circ} 18^{\prime} \mathrm{E}$ & 1091 & 158 & 208 \\
5 & Elum & $6^{\circ} 20^{\prime} \mathrm{N}$ & $1^{\circ} 02^{\prime}, \mathrm{E}$ & 950 & 50 & 35 \\
6 & Bénakuma & $6^{\circ} 26^{\prime} \mathrm{N}$ & $9^{\circ} 02^{\prime} \mathrm{E}$ & 576 & 154 & 132 \\
\hline
\end{tabular}


Table 2: Checklist of plant families and the number of plant species in Kimbi Game Reserve.

\begin{tabular}{|c|c|c|}
\hline S. No. & Family & Number of species \\
\hline 1 & Acanthaceae & 3 \\
\hline 2 & Anarcadiacea & 2 \\
\hline 3 & Annonaceae & 1 \\
\hline 4 & Apocynoceae & 3 \\
\hline 5 & Araliaceae & 1 \\
\hline 6 & Bignoniaceae & 1 \\
\hline 7 & Burseraceae & 1 \\
\hline 8 & Combretaceae & 1 \\
\hline 9 & Commelinaceae & 1 \\
\hline 10 & Compsitae & 2 \\
\hline 11 & Costaceae & 1 \\
\hline 12 & Cyperaceae & 1 \\
\hline 13 & Dracaenaceae & 1 \\
\hline 14 & Euphorbiaceae & 6 \\
\hline 15 & Graminae & 2 \\
\hline 16 & Guttiferae & 1 \\
\hline 17 & Lauraceae & 3 \\
\hline 18 & Leganiaceae & 14 \\
\hline 19 & Malastomocaceae & 1 \\
\hline 20 & Meliaceae & 1 \\
\hline 21 & Monispermaceae & 2 \\
\hline 22 & Moraceae & 2 \\
\hline 23 & Musaceae & 1 \\
\hline 24 & Myristicaceae & 1 \\
\hline 25 & Moraceae & 5 \\
\hline 26 & Musaceae & 1 \\
\hline 27 & Myristicaceae & 1 \\
\hline 28 & Myrtaceae & 1 \\
\hline 29 & Ochnaceae & 3 \\
\hline 30 & Olaceae & 2 \\
\hline 31 & Orchidaceae & 9 \\
\hline 32 & Palmae & 2 \\
\hline 33 & Piperaceae & 2 \\
\hline 34 & Pihosporaceae & 1 \\
\hline 35 & Rhamnaceae & 1 \\
\hline 36 & Rosaceae & 1 \\
\hline 37 & Rubiaceae & 9 \\
\hline 38 & Sapindaceae & 1 \\
\hline 39 & Ulmaceae & 1 \\
\hline 40 & Urticaceae & 1 \\
\hline 41 & Verbenaceae & 1 \\
\hline 42 & Zingiberaceae & 2 \\
\hline 43 & Pendenceae & 1 \\
\hline Total & Number of Species & 98 \\
\hline
\end{tabular}

Source: The conservator, Kimbi Game Reserve.

green forest of the reserve, gallery forests in valleys, natural pastures on the surrounding plains and hills, and the seasonal colours of plants. These create attractive views. The valleys formed by streams and hills enhance the visual value of the area, and topographic structure is an important feature in creating viewpoints. Present day geomorphic processes and the rich and unique biodiversity are of scientific importance and constitute important destinations for scientific tourism. Unfortunately, these resources are under anthropic pressure.

The forest provides local employment and livelihoods. Timber and non-timber forest products are important local economies with the potential for improvement. The forest and lakes also have strong cultural significance. The main land use effects are forest degradation by the unsustainable harvesting of products, slash-andburn shifting cultivation, bush fires and range degradation. Agricultural encroachment is a main threat. The proposed improvement of the road from Wum to Nkambe will enhance forest degradation even more by further increasing market access (Fig. 2) and hence the agricultural value of the area. Cattle range freely within the periphery of the forest during the rainy season and invade it during the dry season. This prevents regeneration. Serious erosion is now occurring in forest margins aggravated by deliberate burning. The present use of land is having deleterious effects. Hunting is evident at the periphery of the reserve. There are old pit traps, old iron traps and traditional trapping using sticks and twine. Some sling hunting occurs, particularly of squirrels and birds. A programme of reafforestation and regeneration of native species needs to be developed for highly degraded areas in forest borders. Inventories of flora and fauna need to be completed. Population monitoring and ecological studies should be carried out on threatened species.

\section{Cultural Landscape}

The villages at the periphery of the reserve and the disaster - prone zone give the area an added attraction of traditional village life, in terms of settlement and variations in land use. The mountain pastures are colonized by seminormadic tribes who keep cattle, sheep, and horses. Farmers settle in village chiefdoms on plains and valleys (Fig. 2). Traditional lifestyle and culture are important and attractive elements for tourists. Traditional architecture is an important element of the cultural landscape, with buildings of wood, bamboo and mud walls and grass-thatched, high, pyramid-like roofs. Numerous carved houseposts support the heavythatched roof with its comparatively wide overhang. Door-frames and door-surrounds are carved with several symbolic motifs. Geological processes, configuration of the land, climate and biogeography have shaped the selection of buildings and construction materials. Festivals providing recreation are important in maintaining 
Table 3: The mammal population recorded in Kimbi Game Reserve.

\begin{tabular}{llll}
\hline S. No. & Family & English name & Scientific name \\
\hline 1 & Colobidae & Black and white colobus & Colobus guereza \\
2 & Cercopthccidae & Olive baboons & Papio anubis \\
3 & Cercipithecinae & patas monkey & Cercopithecus (Erythrocebus) patas. \\
4 & Cercipithecinae & Green monkey & Cercopithecus (caethiop) tantalus \\
5 & Cercipithecinae & Mona monkey & Cercopithecus (mona) mona \\
6 & Lagosmopha/ baridae & Scrub hare & Lepus scxtilis \\
7 & Rodential/ sciuridae & Striped ground squirrel & Euxerus enythropus \\
8 & Rodentiall sciuridae & Red legged sun squirrel & Heliosciurus rufobrackium \\
9 & Rodentiall sciuridae & African gaint squirrel & Protoxerus stergeri \\
10 & Hytrilidae & crested porcupine & Hystrix cristata \\
11 & Thyronomyidae & marsh canerat & Thryonomys gregorianus \\
12 & Cricetomyinae & Ernin's Giant Rat & Cricetomys Emin's \\
13 & Herspestidae & Slender mongoose & Herpestes sanguinea \\
14 & Viverridae & African civet & Civettictis civetta \\
15 & Procavidae & Rock hyrax & Procavia johustoni \\
16 & Bivini & African Buffalo & Syncerus caffer \\
17 & Tragelaphini & Bushbuck & Tragelaphus scriptus \\
18 & Cephalophini & Bay duiker & Cephalophus dorsalis \\
19 & Cephelophini & Blue duiker & Cephalophus monticola \\
20 & Reduncini & Rob & Kobus kob \\
21 & Reduncini & Water Buck & Kobus ellipsiprymus defassa \\
\hline
\end{tabular}

Source: The conservator, Kimbi Game Reserve.

social cohesion in the chiefdoms. Annual festivals and dances in palace chiefdoms are attractions during the dry season. Tourists experience a variety of traditional meals and rites.

The reserve has no accommodation for visitors, a poor and seasonal road network and poorly developed sites and tourist infrastructure in the nearest town (Wum). These facilities are clearly inadequate for the accommodation needs of tourists. Handicraft production which is already on the decline (Knopfli 1990) can be promoted as an integral part of tourism economy. This is important because the observation of handicraft artisans and the buying of souvenirs or art objects draw tourist interest and spending. The government's reserve policy creates parks and reserves that ignore their human neighbours.

\section{SWOT ANALYSIS}

The Kimbi Game Reserve within the Nyos Volcanic District is rich in natural and cultural treasures. The strengths $(\mathrm{S})$, weaknesses $(\mathrm{W})$, opportunities $(\mathrm{O})$ and threats $(\mathrm{T})$ of ecotourism resources were identified:

\section{Strengths and Advantages}

- The area is rich in wildlife (plants and animals) and natural landscapes of touristic and scientific importance.
Table 4: Checklist of birds in Kimbi Game Reserve

\begin{tabular}{|c|c|c|c|}
\hline \multicolumn{2}{|c|}{ Non-Passerines } & \multicolumn{2}{|c|}{ Passerines } \\
\hline Family & $\begin{array}{l}\text { No. of } \\
\text { species }\end{array}$ & Family & $\begin{array}{l}\text { No. of } \\
\text { species }\end{array}$ \\
\hline Ardeidae & 1 & Campephagidae & 2 \\
\hline Anatidae & 1 & Crvidae & 1 \\
\hline Accipttridae & 14 & Dicruridae & 1 \\
\hline Apodidae & 3 & Eurylaidae & 1 \\
\hline Alcedinidae & 8 & Emberizidae & 1 \\
\hline Charadrudae & 1 & Estrildae & 10 \\
\hline Columbidae & 4 & Fringillidae & 1 \\
\hline Cuculidae & 8 & Hirundinidae & 7 \\
\hline Coludae & 1 & Landidae & 2 \\
\hline Capitonidae & 8 & Motacillidae & 4 \\
\hline Caprimulgidae & 1 & Monarchidae & 2 \\
\hline Bucerotidae & 1 & Muscicapioae & 3 \\
\hline Falconidae & 1 & Malaconotidae & 10 \\
\hline Indicatoridae & 1 & Nectarinidae & 11 \\
\hline Jacanidae & 1 & Oriolidae & 2 \\
\hline Musophagidae & 2 & Pycronotidae & 10 \\
\hline Meropidae & 4 & Platysteiridae & 3 \\
\hline Osittacidae & 2 & Paridae & 1 \\
\hline Phasianidae & 2 & Passeridae & 1 \\
\hline Picidae & 3 & Ploceidae & 6 \\
\hline Rallidae & 3 & Syviidae & 24 \\
\hline Scopidae & 1 & Sturnidae & 7 \\
\hline Strigdae & 1 & Thurdidae & 6 \\
\hline Threskiornithidae & 1 & Timalinidae & 2 \\
\hline Upupidae & 1 & Zosteropidae & 1 \\
\hline Total & 74 & Total & 129 \\
\hline Grand Total $=203$ & Specie & of Birds & \\
\hline
\end{tabular}

Source: Summarized from the archival materials of the Kimbi Game Reserve

- It possesses rich cultural values, handicraft production, traditional houses, settlements, festivals, rites and food. 
- Local people are welcoming and have a positive attitude to tourism.

- Annual festivals and dances are organized in chiefdoms (palaces).

- Life is traditional and tranquil in a typical African setting.

- The area has an ecological potential to increase the destinations and experiences for worldwide tourism.

\section{Weaknesses or Disadvantages}

- The area is far from the provincial capital city (Bamenda) and other urban centres.

- There are clearly no tourist infrastructure and service facilities.

- The reserve is grossly under-staffed with no staff educated for tourism.

- The area is enclaved in difficult topography and remote from urban centres. There will be high investment costs.

- Tourism in the region has no advertisement and marketing activities and agencies.

- Local people and tourists are insensitive to environmental issues.

- No master management and development plans to take advantage of the opportunities offered by ecotourism.

- Lack of tourism marketing and promotion agencies.

\section{Opportunities}

- Integrating rural livelihoods in conservation projects for local employment and poverty alleviation.

- Promoting, sustaining and reviving a disappearing cultural heritage.

- Protecting and sustaining the rich biodiversity.

- Promoting the participation of local people in biodiversity protection.

- Promoting tourism and biodiversity conservation by linking culture, the environment and livelihoods.

\section{Threats}

- Total absence of infrastructure and waste disposal systems.

- Increasing human pressure on fauna, flora and natural landscapes.

- Erosion of the cultural values through production and commercialization to suit the taste of tourists and through the adoption of foreign values.

- Poorly structured and unplanned village settlements and houses that can be developed as cultural villages.

- Underdeveloped environmental consciousness and threat of pollution.

- Risks from catastrophic landslides and gas eruptions from crater lakes.

Most local people in the area benefit very little from tourism. An innovative project for the development of ecotourism must alleviate impacts of tourists and maximize the income generating potential of ecotourism. The Kimbi area is the home of people who continue to use resources in a traditional way. This study designs an encouraging model for poor communities.

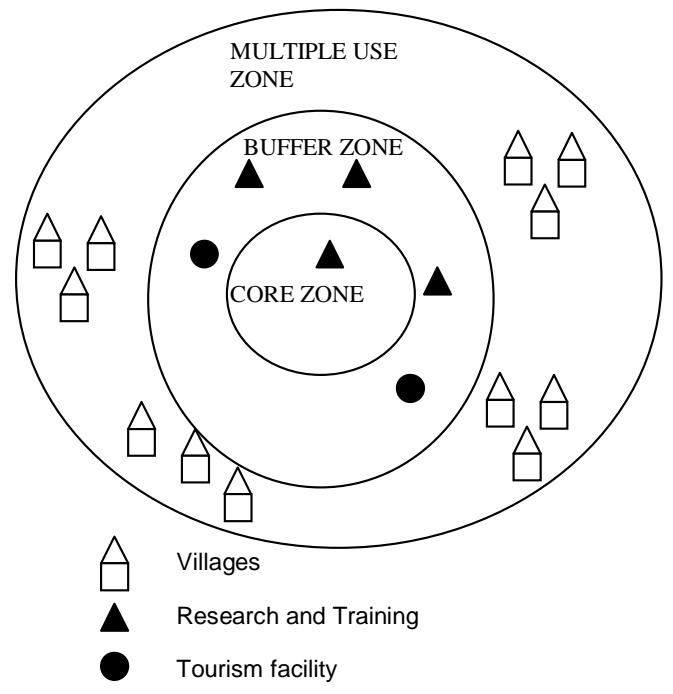

Fig. 3. A model for the integration of ecotourism, rural livelihood and biodiversity protection in traditional societies.

Permanent villages are situated in the multipurpose use area around the reserve. The Kimbi area has a rural population of 1,071 inhabitants according to 2005 statistics. These are people who use resources in traditional ways. The area should be divided into different zones, for example, intensive farming land in the multipurposeuse area, seasonal grazing areas in foothills, special management zones along tourist routes in the core and buffer zones, protected areas with high biological richness in the core zone, protected areas with high cultural richness in the 
multi-use area (villages) and wilderness area in the high peaks. The degassing and monitoring of Lake Nyos can constitute an important element of research and scientific tourism.

There can be no meaningful conservation without the active involvement of local people. Fees paid by visitors should go directly in financing a variety of conservation, education and development projects in the area. Local entrepreneurs can be trained in lodge management, hygiene and marketing. Forest guards can be hired; latrines built, trails repaired, schools and clinics built for local people and provide local tree nurseries for reforestation projects by local people. Recreation throughout the year should be planned, while protecting natural habitats, wildlife and local cultural heritage.

The following are some suggestions to ensure that ecotourism is ecologically and socially beneficial:

- Information on local culture and on sensibilities: Prepare and disseminate information on the history, geography, ecology and culture of the area. This should prevent the violation of local culture and sensibilities.

- Environmental impact: Develop defined trails and camp sites.

- Resource Impact: Minimize the use of scarce resources such as fuel, food and water.

- Cultural impact: Sensitize visitors to respect the privacy and dignity of local people and to be considerate of religious and cultural sites and practices. They should be aware of cultural pollution as well as environmental pollution.

- Wildlife impact: Sensitize visitors not to harass wildlife or disturb plant life, and not to buy animal products such as animal skins, shells and feathers from endangered species.

- Environmental impact: Encourage tourists to contribute to protecting the local environment, that is, to combine ecotourism with work on clean-up campaigns, delivery of educational materials to local schools or to nature clubs.

- Advocacy and education: Visitors should be encouraged to be involved in letter-writing, lobbying, or educational campaigns to help protect the landscapes, culture and biodiversity.

\section{CONCLUSION}

Tropical countries like Cameroon, beleaguered as they are, have established parks and reserves as a way of saving biodiversity. Take a chunk of forest, the reasoning goes, make it a park or reserve, and charge tourists to visit. But parks that ignore their human neighbours and parks that are poorly protected are doomed to fail. Careful planning and investments are required to overcome the weaknesses and threats. In planning most attention should focus on the needs of local people, that is, integrating their culture, livelihoods and environmental awareness in tourism development. In this process local people, government organizations, universities, research institutions and society as a whole must interact sufficiently in order to develop components of interest to ecotourism, ecocultural tourism and scientific tourism. The study posits that the struggle to save species and unique ecosystems cannot be divorced from the boarder struggle to achieve a new world order in which the basic needs of all are met. The development of ecotourism in partnership with local communities and conservation projects can restore local livelihoods. In this way villages can learn how to manage the wildlife and landscapes in a sustainable manner, making sound livelihood decisions without sacrificing their cultural values. Environmental impact and social impact assessments and mitigation strategies are necessary.

\section{REFERENCES}

Alpert P 1993. Conserving biodiversity in Cameroon. Ambio, 22: 33 - 1071

Barkin D 1996. Ecotourism A tool for sustainable deve -lopment. http.//www.planeta.com/planeta/96/0596 (Retrieved, December 14, 1996)

Chambers R 1992. Sustainable livelihoods: The poor's reconciliation of environment and development. In: P Ekins, M Max-Neff (Eds.): Real-life Economics: Understanding Wealth Creation. London: Routledge

Chifos C 2006. Culture - environment and livelihood; potential for crafting sustainable communities in Chiang Mai. Int J Environment and Sustainable Development, 3: 315-332.

Daniel L, Manning R, Krymkowski D 2005. Relationship between visitor-based standards of quality and existing conditions in parks and outdoor recreation. Leisure Science, 27: 157-173.

Gengiz T 2007. Tourism, an ecological approach in protected areas: Keragol-Sahara National Park, Turkey. Int $J$ of Sustainable Development and World Ecology, 14: 260-267

Gregory T 2005. Conflict between global and local land use values in Larvia's Gauja National Park. Landscape Research, 30: 415-430

Hawkins P, Brunt M 1965. Soils and Ecology of West Cameroon. Rome: FAO Report

Jurgens CR 1993. Strategic planning for sustainable rural 
development. Landscape and Urban Planning, 27: 253-258

Knopfli H 1990. Crafts and Technologies: Some Traditional Craftsmen of the Western Grassfields of Cameroon. Part 2: Woodcarvers and Blacksmiths. Basel: Basel Mission Printing Press.

Kwanga MJ 2006. Wildlife management: Case Study of Kimbi Game Reserve. BSc. Long Essay (Unpublished), Yaounde: University of Yaounde.

Leenhartdt O, Menard J, Temdjim R 1990. Rapport sur l'inventaire des lacs maar au Cameroun. Yaounde: Mission Francaise de Coopération.

Lele S 1991. Sustainable development: a critical review. World Development, 19: 607-621

McDonought W, Braungart M 2002. Cradle to Cradle: Remaking the Way We Make Things. New York: North Point Press.

Macleod H 1986. The Conservation of Oku Mountain Forest. Cambridge: ICBP Project Report.

Ndenecho E N 2005. Conserving biodiversity in Africa: Wildlife management in Cameroon. Loyola Journal of Social Sciences, 2: 209-228

Ndenecho EN 2007. Population dynamics, rural livelihoods and forest protection projects in sub-Saharan Africa: experiences from Santa, Cameroon, Int $J$ of Sustainable Development and World Ecology, 14: 250-259

Neefjes K 2000. Environment and Livelihoods: Strategies for Sustainability. London: Oxfam Publishing.

Ngwabuh BA 2002. Annual Report of the Kimbi Game Reserve. Bamenda: NW Delegation for Environment and Forest.

Poiani K, Baumgartner J, Buttnick S, Gren S, Hopkins E, Ivy G, Seaton K, Sutter R 1998. A scaleindependent site conservation planning framework in nature conservation. Landscape and Urban Planning, 43: 143-156

Redchift M 2000. Sustainablity: Life Chances and Livelihoods. London: Routledge.

Sanderson E, Redford K, Veddez A 2002. A conceptual model for conservation planning based on landscape species requirements. Landscape and Urban Planning, 8: 41-56.

Stuart SN 1986. Conservation of Cameroon Mountain Forest. Cambridge: ICBP Project Report. 